\title{
Typical problems in push-rod dilatometry analysis
}

MIRosLaV JANKULA - Department of Physics, Constantine the Philosopher University in Nitra, Slovakia - miroslav.jankula@ukf.sk

Peter ŠíN - Department of Physics, Constantine the Philosopher University in Nitra, Slovakia - peter.sin@ukf.sk

Rudolf PODOBA - Department of Physics, Constantine the Philosopher University in Nitra, Slovakia,andDepartmentof Physics, Slovak University of Technology in Bratislava, Slovakia - rudolf.podoba@ukf.sk

JÁN ONDRUŠKA - Department of Physics, Constantine the Philosopher University in Nitra, Slovakia - jondruska@ukf.sk

Received: 21. 01. 2013. " Érkezett: 2013. 01. 21. " http://dx.doi.org/10.14382/epitoanyag-jsbcm.2013.3

\section{Abstract}

The paper deals with thermodilatometry of green and fired ceramic samples. Problems connected with the measurements in dilatometric practice are described in detail, namely a) the influence of the pressing force of the push-rod, b) the effect of an improperly placed sample and improper measuring range, $c$ ) the influence of the volume of a sample, d) the influence of the heating rate, and e) the influence of the grounding and AD transducer on the results of the thermodilatometric analysis.

Keywords: thermodilatometry, errors, sample, measurement

\section{Introduction}

For the needs of qualitative and quantitative characteristics of the structure and microstructure of ceramics different techniques are used in order to examine their properties, which enables an interpretation of the results of measurements from different points of view. One of these methods is the thermodilatometry. The thermodilatometric analysis (TDA) is based on measuring the volume change of a ceramic sample during heating [1]. Two reasons for the volume change are present in a dry ceramic sample: a) the common thermal expansion due to asymmetric thermal vibrations of the ions in the crystalline lattice, and b) the phase transformation connected with the rearrangement of ions in the crystalline lattice. If we record dilatation changes in a proper way in dependence on the temperature, we can allocate important phase transitions from anomalies of the thermal expansion. The TDA plays an important role in ceramic research. It allows the prediction of the changes in a sample made from known raw materials $[2,3]$. It is also possible to determine the kinetic parameters from thermodilatometry [4]. The effect of texture on thermodilatometry is examined in $[5,6]$. The TDA also plays a very important role in the experimental study of the sintering process $[7,8,9]$.

The thermal volume expansion of materials is characterized by the coefficient $[10,11]$

$\beta=\frac{1}{\mathrm{~V}_{0}} \frac{\Delta \mathrm{V}}{\Delta \mathrm{t}}$,

where $V_{0}$ is the sample volume at the temperature $t_{0}$ (mostly room temperature), $\Delta V$ is the change of the sample volume over a small temperature interval $\Delta t=t-t_{0}$. If the sample is made from an isotropic material and has, for simplicity, a cubic form, then the length of the cube is $l_{0}$ at the temperature $t_{0}$ and $l=l_{0}(1+\alpha \Delta t)$ is its length at the
Miroslav JANKULA

(03.12.1959, Slovakia)

Received his MSc degree from the Military

College in Liptovsky Mikulas, Faculty radiolocation and automated systems in 1982. Post graduated studies at the Catholic University in Ruzomberok, Faculty of Education (graduated in 2009). PhD student at the Constantine the Philosopher University in Nitra, condensed matter physics and acoustics since 2010. Field of research: Thermo-physical properties of building ceramics.

Peter Šín

(12.11.1985, Slovakia) Received his BSc degree from the Constantine the Philosopher University in Nitra, physics and astrophysics in 2007. Received his MSc degree from the Constantine the Philosopher University in Nitra, condensed matter physics and acoustics in 2009. Field of research: Thermo-mechanical and thermo-physical properties of ceramic materials.

Rudolf PODOBA (24.9.1984, Slovakia) Received his MSc degree from the Constantine the Philosopher University in Nitra, physics and computer science in 2009 . Since then he is a $\mathrm{PhD}$ student at the Constantine the Philosopher University in Nitra, condensed matter physics and acoustics. Field of research: Thermal analyses of the green clay ceramic materials.

Ján ONDRUŠKA, PhD.

(19.11.1982, Slovakia)

Received his MSc degree from the Constantine the Philosopher University in Nitra, physics and computer science in 2007. Received his PhD degree from the Constantine the Philosopher University in Nitra, condensed matter physics and acoustics in 2011. Field of research: Thermomechanical and thermo-physical properties of composite materials.

temperature $t$. The sample volume at the temperature $t$ is $V=V_{0}(1+\beta \Delta t)=l_{0}^{3}(1+\alpha \Delta t)^{3} \approx l_{0}^{3}(1+3 \alpha \Delta t)$, if we neglect small terms proportional to the second and third power of $\Delta t$. It results that $\beta=3 \alpha$. Consequently, it is sufficient to measure the length change $\Delta l$ of only one dimension of the sample, and then to calculate the linear coefficient of thermal expansion (CTE) from the formula

$\alpha=\frac{1}{l_{0}} \frac{\Delta l}{\Delta t}$

The CTE belongs to the most important parameters of solid materials used in industry design and research [1]. As it is commonly known, a dilatometer directly measures the quantities $\Delta l$ and $\mathrm{t}$ during heating/cooling/isothermal regime. The initial sample length $l_{0}$ is measured before inserting the sample into the dilatometric cell.

An ideal thermodilatometric analysis (TDA) requires zero mechanical load on the sample, which is unrealizable in practice. Even if no external force acts on the sample, it can be deformed by its own weight. Some non-contact dilatometers, which are suitable to measure $\Delta l$ of soft ceramic samples at high temperatures, use optical methods to record $\Delta l[12$, 13]. Unfortunately, the non-contact dilatometers have some drawbacks, such as the complicated device for recording $\Delta l$.

Most dilatometers apply mechanical contact between the sensor and the sample [14] and employ the differential principle. All contact dilatometers involve an intermediary member (called 
the push-rod) to transmit the dimensional change (caused by subjecting the sample to a temperature change) to the sensor [7].

The areal differential dilatometer works with two samples - a reference and a test sample. It compares changes of dimensions of the samples. The reference sample is mostly made from fused silica (suitable for temperatures up to $900^{\circ} \mathrm{C}$ ) or alumina (suitable for temperatures up to $1500{ }^{\circ} \mathrm{C}$ ) [7].

A push-rod dilatometer is more frequent. Its principle is basically also differential, but the dilatometric cell which is parallel with the measured sample plays the role of the reference sample. The parts of the dilatometric cell are made, in general, from alumina or fused silica and their dependence of the length changes on the temperature is known.

Dilatometers usually use linear variable differential transducer (LVDT) as linear displacement sensor, although one may also use a capacitance sensor (it has high sensitivity but very low range of $\Delta l$ ), optical sensor (based on the interferometer principle; it has a complex construction but high accuracy), digital optical sensor (it is very stable but with the resolution of only $1 \mu \mathrm{m}$ ), and mechanical sensor (it is usually of simple construction with the resolution of $1 \mu \mathrm{m}$ ). Usually, dilatometers need 25 to $50 \mathrm{~mm}$ length samples. This contributes substantially to the measurability and reliability of the data and, therefore, to the overall accuracy of the measured value of $\Delta l / l_{0}[15]$.

Another criterion to distinguish dilatometers is the position of the sample in the dilatometric cell. Most dilatometers employ horizontal position of the sample. A major advantage of the horizontal configuration is its superior thermal uniformity and easy handling with the sample. Moreover, a horizontal furnace is not subjected to convection parallel with the sample [16]. The disadvantage of the horizontal dilatometer is that the push-rod must exert a reasonable force on the sample to overcome the friction between it and the groove. For the trapped end plate, this pressure must also be sufficient to keep the plate pressed against the far side of the groove and does not allow it to move at all [16]. Samples that soften, shrink, or sinter may shorten rather than expand when heated. In this case it is advisable to use a vertical system for shrinkage or sintering investigation. There is no friction between the sample and the dilatometric cell and the force acting on the sample can be decreased to a very small value with the help of a counterweight [16]. A disadvantage is the problematic homogeneity of the temperature field and the necessity to use relatively short and thick samples.

A push-rod dilatometer, as every differential system, needs the calibration by a reference sample $[13,17]$. The forthcoming changes always require recalibration: a replacement of the pushrod, dilatometer tube, or thermocouple, or aging of parts of the dilatometric cell (buckling, cracks, discoloration). Besides, the LVDT is a relatively sensitive device which overall performance depends on the stability and linearity of the signal conditioning network. This fact also requires frequent calibration [18].

The aim of present paper is to describe some typical influences and factors which lead to differences in dilatometric results.

\section{Dilatometry}

The results presented in this contribution were obtained with the help of the push-rod dilatometer described in $[19,20]$. It is a horizontal alumina dilatometer with an LVDT sensor. A constant force assigning reliable mechanical contact between the push-rod, sample, and supporting rod is developed by a weight. The displacement $\Delta l$ of the push-rod is proportional to the change of the output electric signal $\Delta U$,

$\Delta l=k \Delta U=\Delta l_{s}-\Delta l_{a r}$,

where $\Delta l_{s}$ is the change of the sample length and $\Delta l_{a r}$ is the change of the carrier alumina rod length at the temperature $t$. If one uses $l_{0}$ to denote the initial sample length, then

$\frac{\Delta l_{s}}{l_{0}}=\frac{k \Delta U}{l_{0}}+\frac{\Delta l_{a r}}{l_{0}}$.

The calibration was performed by a reference sample (steel X10 NiCrMoTiB 1515) provided by the Physikalisch-Technische Bundesanstalt, Berlin. We used the $\Delta l(t) / l_{0}$ relationship [21] for the reference dilatometric curve in the interval 20 to 1000 ${ }^{\circ} \mathrm{C}$. The polynomial expression of the relationship is

$\left(\frac{\Delta l(t)}{l_{0}}\right)_{\text {ref }}=-4 \times 10^{-22} t^{3}+2 \times 10^{-7} t^{2}+0.0018 t-0.045$,

where $\mathrm{t}$ is the temperature in ${ }^{\circ} \mathrm{C}$ and the relative thermal expansion is given in $\%$.

\section{Influence of different factors on the TDA}

\subsection{Mechanical pressure on the sample}

Reliable mechanical contacts between the push-rod and the sample as well as between the sample and the supporting rod guarantee correct dilatometric results. The push-rod must be pressed against the sample and the supporting rod, i.e., the sample is under the pressure load. The force acting on the sample is relatively small and does not cause contraction if the sample is solid and firm. However, the pressing force significantly influences the TDA at higher temperatures if the sample contains glassy phase or if sintering takes place. For example, it is well known that the bending of the dilatometric curve of glass above the transformation point is caused by the pressing force [22].

If the pressing force is created by spring then the force is not the same when samples of different lengths are used (see Fig. 1). The longer the sample, the larger is the force of the spring. A ceramic sample which contains glassy phase softens above $\sim 900{ }^{\circ} \mathrm{C}$ and contracts under the pressing force. The same behaviour can be confirmed by the dilatometer when the constant pressing force was realized by a weight (see Fig. 2). As Fig. 1 and Fig. 2 indicate, the dilatometric curves for all the samples are identical if their temperatures are under the transformation point of the glassy phase.

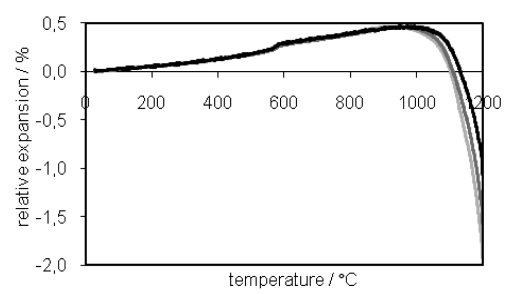

Fig. 1. TD curves of porcelain samples with different lengths: $45 \mathrm{~mm}$, (light grey), $43.5 \mathrm{~mm}$ (grey), $42 \mathrm{~mm}$ (black)

1. ábra Különböző méretü porcelán minták TD görbéi: 45 mm, (világosszürke), 43.5 mm (szürke), $42 \mathrm{~mm}$ (fekete) 


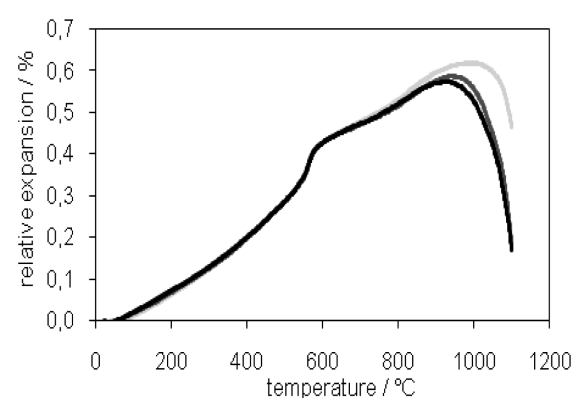

Fig. 2 TD curves of fired brick samples. Pressing force: $0.3 \mathrm{~N}$ (light grey), $0.4 \mathrm{~N}$ (grey), $0.5 \mathrm{~N}$ (black)

2. ábra Kiégetett tégla minták TD görbéi. Nyomóerő: $0.3 \mathrm{~N}$ (világosszürke), $0.4 \mathrm{~N}$ (szürke), $0.5 \mathrm{~N}$ (fekete)

\subsection{Sample position}

If the sample is not exactly parallel with the alumina rods, it can lead to higher friction and sudden small movements of the sample during the measurement. The results are disruptions on the dilatometric curve, as illustrated in Fig. 3.

For all dilatometers, some routine maintenance and inspection is required to assure proper operation and, therefore, accurate results. The sample chamber for any dilatometer must be free of earlier deposits or debris prior to loading the sample and running a test. The transducers require periodic maintenance depending on the cleanness of the environment in which the instrument is operated $[23,24]$. Otherwise, results similar to those showed in Fig. 3 can be obtained.

\subsection{Measuring interval}

If the measuring interval is improperly set, it can cause a loss of the mechanical contact between the push-rod and the sample or the movement of the push-rod can be out of the range of the LVDT. It may occur when the contraction of the sample is too high (see Fig. 4). For correct measurements the operator has to predict the behaviour of the measured sample.

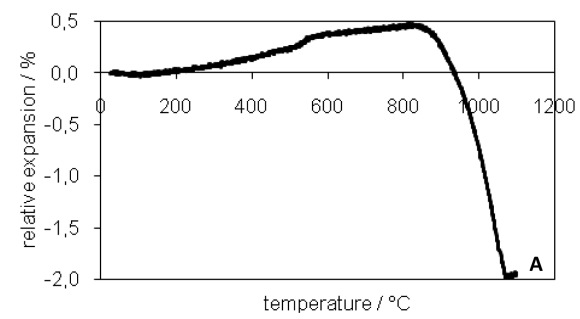

Fig. 3. Shifts of the TD curve caused by sudden movement of the sample due to improper sample insertion to the dilatometer

3. ábra A TD görbe lépcsözetessége a minta elmozdulása miatt, amelynek oka a dilatométerben történő helytelen elhelyezés

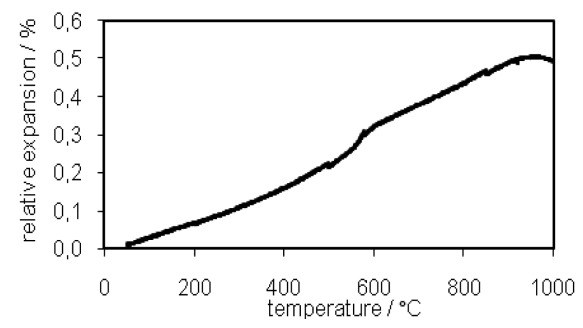

Fig. 4. Loss of mechanical contact between the push-rod and the sample at point A.

4. ábra Érintkezés megszünése a minta és a támasztórúd között az A pontban

\subsection{Heating rate}

The effect of the heating rate on the TDA produces shifts between TD curves (see Fig. 5). This effect is typical for thermal analyses and can be found in the DTA, TGA, and others [2]. The shifts are visible in Fig. 5 at different heating rates caused by the change in the heating rate. At a higher heating rate the temperature is no more uniformly distributed in the complete sample, so one can observe some delay in the relative expansion.

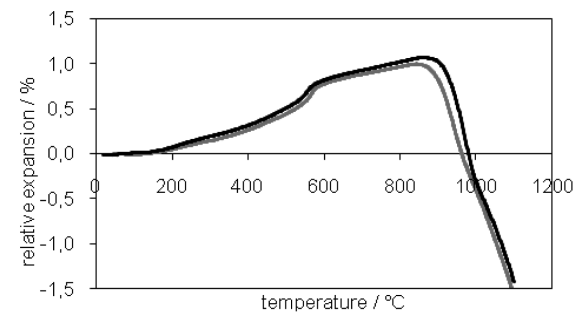

Fig. 5. TD curves of green brick samples at different heating rates: $2.5^{\circ} \mathrm{C} / \mathrm{min}$ (grey) and $10^{\circ} \mathrm{C} / \mathrm{min}$ (black).

5. ábra Ki nem égetett tégla minták TD görbéi eltérö felfütési hömérséklet mellett: 2.5 ${ }^{\circ} \mathrm{C} /$ perc (szürke) és $10^{\circ} \mathrm{C} /$ perc (fekete).

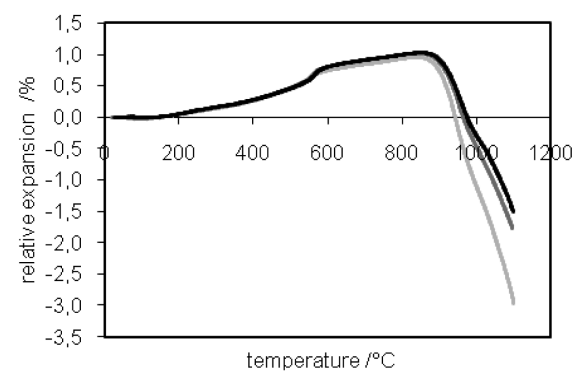

Fig. 6. TD curves of green brick samples with different diameters: $5 \mathrm{~mm}$ (light grey), $8 \mathrm{~mm}$ (grey) and $12 \mathrm{~mm}$ (black)

6. ábra Eltérő átmérőjü, ki nem égetett tégla minták TD görbéi: $5 \mathrm{~mm}$ (világosszürke), $8 \mathrm{~mm}$ (szürke) és $12 \mathrm{~mm}$ (fekete)

\subsection{Size of the sample}

Fig. 6 shows the influence of the sample diameter on TDA results. The larger is the diameter, the more delayed is the start of the high temperature reaction in the sample. Consequently, the curves for larger samples are shifted to higher temperatures. The explanation is similar as in Chapter 3.4, i.e. the changes in the sample volume are faster in the sample with a smaller diameter. In these samples one may observe the high temperature reactions at lower temperatures than at samples with a larger diameter.

\subsection{Electronic circuits}

Differences of the voltage signal from the LVDT are relatively small $\left(\sim 10^{-5} \mathrm{~V}\right)$, therefore, a linear amplifier is necessary. It is evident that correct operation of all electronic devices is essential for obtaining correct results. For example, an incorrect grounding between the LVDT and the amplifier causes noise which is revealed in the dilatometric curve, the latter becoming thick.

Another important influence on the measured data is due to the $\mathrm{AD}$ transducer. If it has small bit resolution then the amount of measured data are represented as the same digital 
number. On the other hand, near the bit boundary a small change of measured data is attended by a large change of the displayed data. As a result, the dilatometric curve contains altering thick parts.

\section{Conclusions}

In this paper, thermodilatometry of green and fired samples made from kaolinitic and illitic clays was performed. Detailed analysis of the dilatometer operation led to the following conclusions.

1. The pressing force does not influence the dilatometric results if the sample volume is solid. Above the temperature at which liquid phase is formed, the pressing force can shorten the sample and significantly influence the dilatometric results.

2. If the pressing force is produced by spring then longer samples are subjected to larger pressing force than shorter samples.

3. If the sample is not properly placed (if it is not parallel and coaxial), it causes "jumps" in the dilatometric curve.

4. Phase changes are registered at lower temperatures if low heating rate is used.

5. Phase changes are registered at lower temperatures if thin sample is used.

\section{Acknowledgements}

The work was supported by the grant VEGA 1/646/12.

\section{References}

[1] Naofumi, Y. - Remi, A. - Masahiro, O.: A calibration method for measuring thermal expansions with a push-rod dilatometer. Measurement Science and Technology 12 (2001) pp. 2121-2129.

[2] Rath J. - Pospíšil, Z. et al: Jemnákeramika - metodikaměření a zkoušek. SNTL/Alfa, Praha, 1988.

[3] Hanykýř, V. - Kutzendorfer, J.: Technologie keramiky. Silis Praha a Vega, Hradec Králové, Praha, 2000.

[4] Feng, K. - Lombardo, S. J.: Kinetic analysis from dilatometry and mass spectrometry measurements of the decomposition and sintering of calcium carbonate. Journal of Ceramic Processing Research 3 (2002) pp. 101-108.

[5] Štubňa, I. - Trnovcová, V.: The effect of texture on thermal expansion of extruded ceramics. Ceramics-Silikáty 42, 1 (1998) pp. 21-24.

[6] Štubňa, I. - Vozár, L. - Smetanková, G.: Thermodilatometry of Textured Electroceramic Material. Termophysics 2001, UKF Nitra, 2001, pp. 105109.

[7] Technical Note 69 Principles of the push-rod dilatometry, available online: HUhttp://www.yeonjin.com/xe/index.php?listStyle=gallery\&page $=$ 5\&document_srl=133UH

[8] Porat, R. - Berger, S., Rosen, A. (1996) "Dilatometric study of the sintering mechanism of nanocrystalline cemented carbides", HNanostructured MaterialsH 7, 4 (1996) pp. 429-436.

[9] Holková, Z. - Pach, L. - Kovár, V. - Svetlík, Š.: Kinetic study of $\mathrm{Al}_{2} \mathrm{O}_{3}$ sintering by dilatometry. Ceramics-Silikáty 47, 1 (2003) pp. 13-19.

[10] Brož, J.: Základy fyzikální chměření. SPN, Praha, 1983

[11] Kittlel, C.: Introduction to the Solid State Physics. Wiley, New York, 1953

[12] Paganelli, M.: Using the optical dilatometer. American Ceramic Society Bulletin 81, 11, pp. 25-30. 2002

[13] Watanabe, H. - Yamada, N. - Okaji, M.: Development of a Laser Interferometric Dilatometer for Measurements of Thermal Expansion of
Solids in the Temperature Range 300 to $1300 \mathrm{~K}$. International Journal of Thermophysics 23, 2002/2, pp. 543-554.

[14] James, J. D. - Spittle, J. A. - Brown, S. G. R. - Evans, R. W.: A review of measurement techniques for the thermal expansion coefficient of metals and alloys at elevated temperatures. Measurement Science and Technology 12, 2001, pp. R1-R15.

[15] Technical Note 58 Use of thermo-mechanical analyzers (tma) for dilatometric measurements, available online: HUhttp://www.yeonjin.com/xe/ $?$ module $=$ file $\&$ act $=$ procFileDownload $\&$ file_srl $=22068 \& \operatorname{sid}=$ eff750717e686f196cc54b07947050a2UH

[16] Technical Note 106 Horizontal vs. vertical dilatometers, available online: http://thermophysical.tainstruments.com/PDF/technotes/TPN-106\%20 Horizontal\%20vs.\%20Vertical \%20Dilatometers.pdf

[17] Yamada, R. A. - Masahiro, O.: A calibration method for measuring thermal expansion with a push/rod dilatometer. Measurement Science and Technology 12, 2001, pp. 2121-2129.

[18] Technical Note 105 The advantages of digital displacement transducer over $L V D T$, available online:

HUhttp://www.yeonjin.com/xe/?module=file\&act= procFileDownload\&file_srl $=22063 \&$ sid $=$ 277 eccb8660f9736c032d2b17c75b5cdUH

[19] Karafa, B. - Štubňa, I. - Vozár, L.: High-temperature horizontal dilatometer. Proc. Calorimetric seminar 2002, Ostravskáuniv., Ostrava, 2002, pp. 5760. (in Slovak)

[20] Štubňa, I. - Vozár, L.: High-temperature Alumina Rod Dilatometer. Proc. of Meeting of the Thermophysical Society THERMOPHYSICS 2000, UKF Nitra, 2000, pp. 77-81.

[21] Štubňa, I. - Važanová, A. - Varga, G. - Hrubý, D.: Simple push-rod dilatometer for dilatometry of ceramics. Research and teaching of physics in the context of university education, SPU Nitra 2007, pp. 69-74.

[22] Hlaváč, J.: Základy technologie silikátů. SNTL, Praha, 1981

[23] Technical Note 61 General dilatometer maintenance, available online: HUhttp://www.yeonjin.com/xe/?module=file\&act= procFileDownload\&file_srl $=22067 \&$ sid $=$ 5b01eee94f585d94bab2e2a21187b2bbUH

[24] Technical Note 109 General dilatometer maintenance, available online: HUhttp://www.yeonjin.com/xe/?module=file\&act $=p$ rocFileDownload\&file_srl=22061\&sid= ee47d3b428c0c6618d41405ed84333c5UH

Ref.: Miroslav Jankula - Peter Šín - Rudolf Podoba - Ján Ondruška: Typical problems in push-rod dilatometry analysis. Építőanyag, 65. évf. 1. szám (2013), 11-14. p. http://dx.doi.org/10.14382/epitoanyag-jsbcm.2013.3

\section{Jellegzetes problémák nyomórudas}

dilatométeres vizsgálatnál

A cikk ki nem égetett és kiégetett kerámia minták termodilatometriai mérésének jellegzetességeit elemzi és részletesen bemutatja a méréshez kapcsolódó egyes jellegzetes méréstechnikai nehézségek következményeit. Bemutatásra kerül a minta támasztó rúd nyomásának a hatása, a nem megfelelốen elhelyezett minta hatása, a nem megfelelô méréshatár választásának a hatása, a minta térfogatának a hatása, a felfútés sebességének a hatása, a nem megfelelő földelés hatása és a mérôátalakító hatása. A vizsgálatok igazolják, hogy abban az esetben, ha cseppfolyós fázis jön létre a vizsgálat közben, a minta támasztó rúd nyomása jelentốs a hatást gyakorol a termodilatometriai mérés eredményére. Amennyiben a nyomást rugó fejti ki, úgy a vizsgálati minta mérete jelentôsen befolyásolja a mérési eredményt. Ha a vizsgálati minta elhelyezése nem párhuzamos és központos, akkor a mérési eredmények hibásak lehetnek. A termodilatometriai mérés eredményét jelentôs mértékben befolyásolhatja a felfútés sebessége a vizsgálat során, illetve a vizsgálati minta vastagsága.

Kulcsszavak: termodilatometria, mérési hiba, vizsgálati minta, mérés 